ISSN: 1858-4837;E-ISSN: 2598-019X

Volume 16, Nomor 1 (2021)

https://jurnal.uns.ac.id/region

DOI: 10.20961/region.v16i1.35122

\title{
Persepsi aparat dan masyarakat pada implementasi teknologi geospasial dalam efisiensi pelayanan skala kelurahan
}

\author{
Perception of community and official on geospatial technology implementation \\ for public service efficiency at urban village
}

\author{
R A Putri ${ }^{1,2}$, E F Rini ${ }^{1,2}$, M J Rahayu ${ }^{1,2}$, P Rahayu ${ }^{1,2}$ \\ ${ }^{1}$ Program Studi Perencanaan Wilayah dan Kota, Fakultas Teknik, Universitas Sebelas \\ Maret \\ ${ }^{1}$ Pusat Informasi dan Pembangunan Wilayah, Lembaga Penelitian dan Pengabdian \\ kepada Masyarakat, Universitas Sebelas Maret
}

Corresponding author's email: rufia.putri@staff.uns.ac.id

\begin{abstract}
Abstrak. Di era digital modern saat ini, efisiensi pelayanana publik sangat dipengaruhi oleh kapasitas aparat dan digitalisasi sistem pelayanan. Terkait dengan tingkat pelayanan pada skala kelurahan, perubahan guna lahan dan berbagai informasi yang terkait dengan ruang bisa sangat dinamis. Perpindahan penduduk, perubahan fungsi bangunan, maupun aktivitas masyarakat yang berpengaruh pada ruang bisa terjadi sewaktu-waktu. Terkait dengan dinamika ini, ketersediaan sistem digital dan kapasitas aparat serta masyarakat yang mampu mengoperasikan sistem tersebut, dapat menjadi tonggak bagi sistem pelayanan publik skala kelurahan yang lebih baik dan efektif. Dengan menggunakan studi kasus dan instrument kuesioner dengan skala likert, pada aparat dan masyarakat, penelitian ini mengindikasikan bahwa pemahaman aparat dan masyarakat pada pentingya peningkatan efektifitas pelayanan publikk melalui implementasi teknologi dapat terbuka melalui difusi informasi melalui kerjasama dengan akademisi. Pelatihan yang efektif sangat diperlukan untuk meningkatkan kapasitas aparat dan masyarakat terkait operasionalisasi sistem digital dalam penataan ruang, khususya SIG (Sistem Informasi Geografis).
\end{abstract}

Kata Kunci: Partisipasi; Pemetaan; Perencanaan Lingkungan Hunian; Pertumbuhan Perkotaan; SIG

Abstract. In the modern digital era, the efficiency of public services is greatly influenced by the capacity of the apparatus and digitalization of the service system.

Received: October 1, 2019; Accepted: October 22, 2019; Available online: January 30, 2021

Copy right $\odot$ 2021, REGION: Jurnal Pembangunan Wilay ah dan Perencanaan Partisipatif 
Regarding the level of service at the scale of urban village, land use change and various information related to space can be very dynamic. Population mobility, changes in building functions, and community activities that affect space can occur at any time. Related to this dynamic, the availability of digital systems and the capacity of public officials to operate the system, can be a milestone for a better and more effective urban public service. By using case study with Likert scale questionnaire as instrument to collect primary data, this research indicates that the understanding of the apparatus and community on the importance of increasing the effectiveness of public services through the implementation of technology can be achieved through diffusion of information conducted collaboratively with academics. As part of that, effective training to increase the capacity of officials and community about the operation of digital systems in spatial planning, specifically GIS (Information Systems Geographical) is crucial.

Keywords: GIS; Mapping; Neighborhood Planning; Participatory; Urban Growth

\section{Pendahuluan}

Implementasi teknologi geospasial berupa sistem informasi geografis bertujuan untuk mempermudah akses penyimpanan data informasi berupa atribut spasial dan non spasial. Teknologi ini memungkinkan pengguna memperoleh data yang akurat dan faktual atas atribut lokasi yang dibutuhkan. Dalam kaitannya dengan tata ruang, SIG mampu mendukung pelayanan publik pemerintah baik dalam perumusan kebijakan perencanaan, pemanfaatan, maupun pengendalian tata ruang. Akan tetapi, sebagai birokrasi level terbawah Pemerintah Kota, kelurahan seringkali memiliki keterbatasan sumber daya, baik kapasitas aparat terhadap penguasaan teknologi maupun ketersediaan prasarana (hardware) yang mampu mendukung penerapan teknologi geospasial.

Adapun beberapa masalah yang umumnya dihadapi oleh kelurahan adalah: (1) Tidak memiliki perangkat keras dengan spesifikasi yang cukup untuk sistem informasi geografis kelurahan; (2) Tidak memiliki peta kelurahan yang merepresentasikan keseluruhan informasi dasar keruangan terkini sebagai basis data digital, dan (3) Belum memiliki sumber daya manusia yang cakap dalam mengoperasikan sistem informasi geografis kelurahan.

Sistem Informasi Geografis itu sendiri adalah perangkat lunak, perangkat keras, maupun aplikasi-aplikasinya, yang telah dikenal secara luas sebagai alat bantu (proses) pengambilan keputusan. Sebagian besar institusi pemerintah, swasta, akademis maupun non akademis juga individu yang memerlukan informasi yang berbasiskan data spasial telah mengenal dan menggunakan sistem ini [1].

Beberapa penelitian sebelumnya menunjukkan bahwa Sistem Informasi Geografis berperan penting dalam meningkatkan efisiensi terkait dengan perencanaan ruang kota dan wilayah. Sebagai contoh, pemanfaatan SIG pada sistem persampahan padat dapat memberikan informasi terkait pengelolaan dan transmisi sampah langsung dari lokasi pembuangan sampah, dan lokasi lainnya yang terkait, dengan biaya yang murah [2]. SIG juga bisa 
dimanfaatkan dalam pemetaan dan pengelolaan sungai dan air tanah dengan melalukan overlay peta tematik [3]. SIG juga bisa digunakan dalam pemodelan untuk perawatan jaringan jalan [4].

SIG juga banyak digunakan dalam pengelolaan guna lahan kota. Antara lain, pemanfaatan SIG untuk melakukan penilaian pada area perkotaan yang layak huni (liveable), dengan menerapkan 15 indikator layak huni yang dianalisis dengan SIG [5]. Selain itu, perubahan tutupan lahan juga membutuhkan SIG untuk pengamatan yang detil dan akurat, dengan biaya yang relatif rendah [6]. Analisis Land Use Land Cover (LULC) ini mampu menunjukkan hubungan antara aktivitas manusia dan lingkungan secara akurat [6].

Karena besarnya manfaat SIG terkait dengan efisiensi berbagai kegiatan yang terkait dengan pelayanan publik tersebut, maka salah satu indikator kinerja Pemerintah dalam menjalankan pelayanan publik adalah kemampuannya memanfaatkan informasi geospasial yang bersifat faktual dan dapat diakses sesuai kebutuhan penggunaannya. Tampilan digital data menjadikan proses penyimpanan, pembaharuan dan penambahan jauh lebih efisien dan mudah diakses kembali [7]. Hal ini memudahkan pengguna dalam mendukung proses pengambilan keputusan dimana data menjadi input utama dalam pertimbangannya [8].

Terkait dengan pentingnya peran SIG dalam peningkatan efisiensi pelayanan publik secara teoritis, terutama pada aktivitas perkotaan yang langsung terkait dengan masyarakat, skala administrasi terkecil memegang peranan penting. Oleh karena itu, tujuan dari studi ini adalah untuk mendapatkan penilaian masyarakat dan aparat terkait dengan peran SIG dalam pelayanan publik dengan menggunakan kelurahan sebagai unit administrasi yang langsung terkait dengan masyarakat dan aktivitasnya.

\section{Metode}

Penelitian ini adalah penelitian deduktif dengan metoda studi kasus. Metoda studi kasus adalah pendekatan yang dilakukan untuk memahami suatu kasus yang spesifik secara detail, dengan menggunakan data kuantitatif dan kualitatif [9]. Penelitian ini dilakukan dalam dua tahap. Tahap pertama adalah pengumpulan data spasial yang dilakukan melalui observasi lapangan. Observasi lapangan dilakukan untuk mendapatkan pemahaman tentang kondisi kelurahan yang menjadi wilayah studi, serta untuk mendapatkan data terbaru untuk pembuatan peta guna lahan digital kelurahan. Observasi lapangan dan pembuatan peta digital juga dilakukan untuk memberikan contoh dan pemahaman pada aparat kelurahan dan masyarakat akan manfaat SIG pada skala Kelurahan.

Tahap kedua adalah memberikan kuesioner dengan skala likert yang dilengkapi beberapa pertanyaan terbuka, pada beberapa aparat kelurahan dan masyarakat yang terlibat dalam pelatihan SIG. Pada kuesioner digunakan Instrumen Likert dengan 5 skala penilaian (lihat Tabel 1), dan beberapa pertanyaan terbuka, untuk mendapatkan penilaian aparat dan anggota masyarakat pada beberapa hal yaitu (1) tingkat kepentingan sistem digital khususnya SIG pada skala kelurahan, (2) tingkat kepentingan kerjasama dengan akademisi untuk membuka wawasan masyarakat dan aparat terkait dengan SIG dan pelayanan umum 
kepada masyarakat yang lebih efektif. Enam belas aparat kelurahan dan anggota masyarakat menjadi respoden pada studi ini.

Dua kelurahan menjadi kasus studi, yaitu Kelurahan Bumi dan Sondakan. Kelurahan Bumi dan Sondakan merupakan kelurahan yang terletak di Kecamatan Laweyan, Kota Surakarta. Sesuai dengan prasyarat pemilihan kasus studi dalam Yin [9], kedua kelurahan tersebut dipilih karena memiliki karakterisik spesifik sebagai berikut:

(1) Sudah memiliki sumber daya dasar yang dibutuhkan dalam pembangunan basis data, namun belum mengenal teknologi dan kepentingan pengendalian pemanfaatan ruang. Dengan kata lain, kedua kelurahan tersebut belum memiliki sumber daya manusia yang cakap dalam mengoperasikan sistem informasi geografis kelurahan

(2) Pelayanan publik yang bersifat spasial masih didasarkan oleh data yang berasal dari kegiatan pendataan pemanfaatan ruang konvensional dan tanpa adanya pelibatan masyarakat di dalamnya.

(3) Tidak memiliki perangkat keras dengan spesifikasi yang cukup untuk sistem informasi geografis kelurahan serta tidak memiliki perangkat lunak untuk menyusun basis data secara digital. Oleh karena itu, kekurahan yang menjadi kasus studi dalam penelitian ini tidak memiliki basis data spasial yang menunjukkan arahan maupun pemanfaatan ruang terkini

(4) Tidak memiliki peta kelurahan yang merepresentasikan keseluruhan informasi dasar keruangan faktual

Untuk mengoptimalkan potensi dan mereduksi masalah pada kondisi daerah studi dengan status di atas, diperlukan implementasi teknologi geospasial secara berkelanjutan oleh aparat kelurahan, dengan didukung oleh masyarakat sebagai ujung tombak pembaharuan data spasial secara faktual. Penilaian persepsi aparat dan masyarakat dengan skala likert disusun berdasarkan poin-poin permasalahan dapat dilihat pada Tabel 1 sebagai berikut.

Tabel 1. Instrumen penilaian persepsi masyarakat.

\begin{tabular}{|c|c|c|}
\hline Permasalahan Kelurahan & Solusi & Persepsi Masyarakat dan Aparat \\
\hline $\begin{array}{l}\text { - Tidak memiliki perangkat } \\
\text { keras dengan spesifikasi yang } \\
\text { cukup untuk sistem informasi } \\
\text { geografiskelurahan } \\
\text { - Tidak memiliki perangkat } \\
\text { lunak untuk menyusun basis } \\
\text { data secara digital }\end{array}$ & 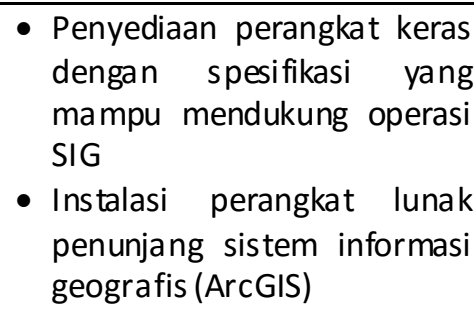 & $\begin{array}{l}\text { - Peningkatan dan penyediaan perangkat keras } \\
\text { SIG skala kelurahan adalah hal yang penting- } \\
\text { (likertdanjelaskan) } \\
\text { - Instalasi perangkat Iunak SIG bagi peningkatan } \\
\text { efisiensi pelayanan publik tingkat kelurahan } \\
\text { sangat dibutukan-(skala likert } 5 \text { dan jelaskan) }\end{array}$ \\
\hline $\begin{array}{l}\text { - Tidak memiliki peta kelurahan } \\
\text { yang merepresentasikan } \\
\text { keseluruhan informasi dasar } \\
\text { keruangan faktual } \\
\text { - Tidak memiliki basis data } \\
\text { spasial yang menunjukkan } \\
\text { arahan maupun pemanfaatan } \\
\text { ruang terkini }\end{array}$ & $\begin{array}{l}\text { Berbasis informasi geografis } \\
\text { dan visualisasi dalam bentuk } \\
\text { peta }\end{array}$ & $\begin{array}{l}\text { - Aparat dan kelurahan selama ini mengalami } \\
\text { kesulitan dalam memperbaharui data spasial- } \\
\text { (skala likert } 5 \text { danjelaskan) } \\
\text { - Data digital spasial yang terintegrasi pada ArcGIS } \\
\text { pada skala kelurahan adalah penting dan } \\
\text { bermanfaat (skalalikert } 5 \text { dan jelaskan) } \\
\text { - Peta digital dapat meningkatkan efisiensi } \\
\text { pelayanankelurahan-(skala likert } 5 \text { danjelaskan) }\end{array}$ \\
\hline
\end{tabular}




\begin{tabular}{|c|c|c|}
\hline Permasalahan Kelurahan & Solusi & Persepsi Masyarakat dan Aparat \\
\hline $\begin{array}{l}\text { - Sumber daya manusia masih } \\
\text { belum } \\
\text { mengoperasikan mampu } \\
\text { informasi geografis kel urahan }\end{array}$ & $\begin{array}{l}\text { - } \text { Penyusunan modul } \\
\text { operasionalisasi sistem } \\
\text { informasi geografis berbasis } \\
\text { ArcGIS } \\
\text { - Workshop pembaharuan dan } \\
\text { penggunaan informasi } \\
\text { geografis menggunakan } \\
\text { ArcGIS }\end{array}$ & $\begin{array}{l}\text { - SIG mudah dipahami (skala likert5 dan jelaskan) } \\
\text { - Workshop Sistem Informasi Geografis berbasis } \\
\text { ArcGIS efisien dalam membantu pemahaman } \\
\text { implementasiSIG-(skala likert } 5 \text { dan jelaskan) } \\
\text { - SIG dapat diterapkan di kelurahan secara } \\
\text { menerus-(skala likert } 5 \text { dan jelaskan) }\end{array}$ \\
\hline
\end{tabular}

\section{Hasil dan pembahasan}

Kegiatan pelatihan dari akademisi kepada masyarakat dan aparat Kelurahan Bumi dan Sondakan (lihat Gambar 1 dan Gambar 2) bertujuan memberikan kemampuan kepada aparat dan masyarakat di mitra kelurahan untuk mengoperasikan aplikasi ArcGIS 10.3. Dengan menggunakan aplikasi ArcGIS 10.3, aparat dan masyarakat diharapkan dapat melakukan pembaharuan dan penggunaan data pada peta yang telah disusun oleh akademisi bagi kedua kelurahan tersebut. Selanjutnya, implementasi teknologi sistem informasi geografis dapat menjadi alat bantu informasi dan pengendalian pemanfaatan ruang di kedua kelurahan. Materi workshop yang diberikan, meliputi:

(1) Pengenalan fungsi ArcGIS;

(2) Pengenalan tools ArcGIS;

(3) Penyusunan peta dasar;

(4) Mengedit attribute table;

(5) Pembuatan jalan (polyline);

(6) Pembuatan area (polygon);

(7) Pembuatan titik sarana (point);

(8) Menghitung luasan wilayah dan panjang; dan

(9) Penyusunan simbologi.

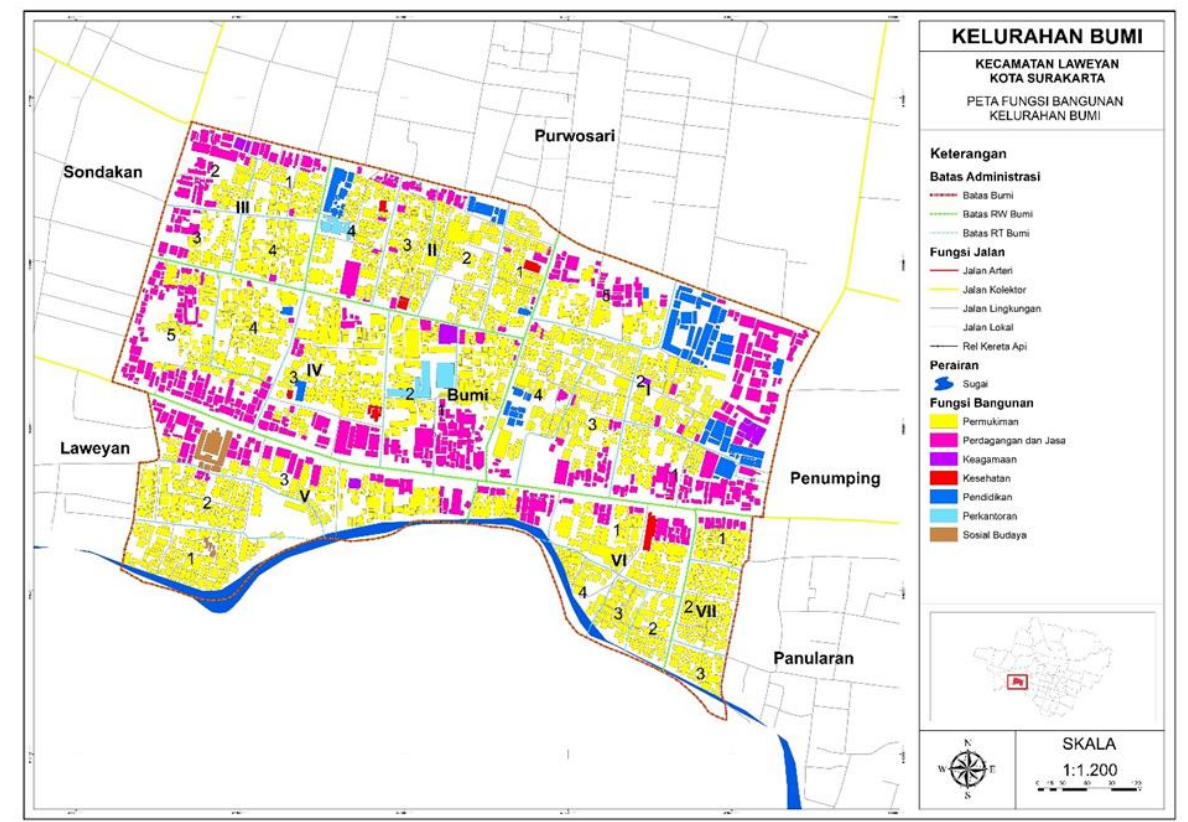

Gambar 1. Peta Kelurahan Bumi.

Received : October 1, 2019; Accepted: October 22, 2019; Available online: January 30, 2021 


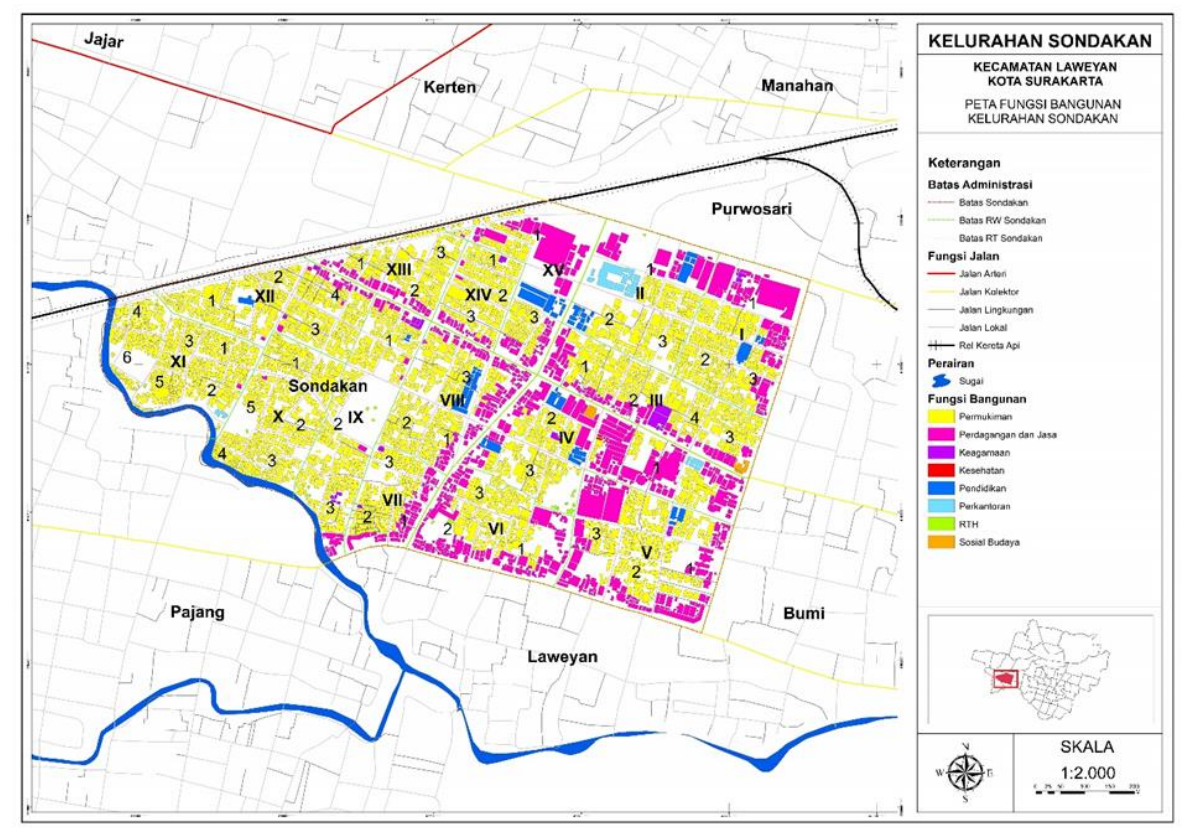

Gambar 2. Peta Kelurahan Sondokan.

Berdasarkan kuesioner yang diberikan pada peserta workshop SIG yang diikuti oleh aparat dan masyarakat Kelurahan Bumi dan Sondakan memberikan penilaian yang positif pada kegiatan dan penerapan data spasial digital pada skala kelurahan. Dengan hasil rata-rata penilaian dari partisipan dapat dilihat pada Tabel 2 sebagai berikut pada skala 1 sampai dengan 5 dari sangat tidak setuju sampai sangat setuju.

Tabel 2. Hasil kuesioner persepsi peserta.

\begin{tabular}{lc}
\hline \multicolumn{1}{c}{ Pertanyaan } & Rata-Rata \\
\hline Instalasi perangkat keras dan lunak SIG bagi peningkatan efisiensi pelayanan publik tingkat & 4.5 \\
kelurahan sangat dibutukan & 4.2 \\
Aparat dan masyarakat kelurahan selama ini mengalami kesulitan dalam memperbaharui & \\
data peta/data spasial & 4.6 \\
Data digital untuk input pada peta (data digital spasial) yang terintegrasi pada ArcGIS pada & 4.6 \\
skala kelurahan adalah penting dan bermanfaat & 3.8 \\
Peta digital dapat meningkatkan efisiensi pelayanankelurahan & 4.6 \\
SIG mudah dipahami & 4.3 \\
Workshop Sistem Informasi Geografis berbasis ArcGIS efisien dalam membantu pemahaman \\
implementasiSIG
\end{tabular}

Dari tabel penilaian persepsi partisipan tersebut dapat diinterpretasikan bahwa masyarakat dan aparat cenderung sangat setuju pada tiga pernyataan berikut (1) instalasi perangkat keras dan lunak SIG bagi peningkatan efisiensi pelayanan publik tingkat kelurahan sangat dibutukan, (2) data digital untuk input pada peta (data digital spasial) yang terintegrasi pada ArcGIS pada skala kelurahan adalah penting dan bermanfaat, (3) peta digital dapat meningkatkan efisiensi pelayanan kelurahan, dan (4) workshop Sistem Informasi Geografis Received : October 1, 2019; Accepted: October 22, 2019; Available online: January 30, 2021 Copy right $\odot$ 2021, REGION: Jurnal Pembangunan Wilay ah dan Perencanaan Partisipatif 
berbasis ArcGIS efisien dalam membantu pemahaman implementasi SIG, dengan rata-rata nilai likert 4.5 dan 4.6 dari nilai maksimal 5. Dengan demikian, data digital, perangkat lunak dan keras, serta proses fasilitasi oleh civitas akademika dianggap sangat penting bagi peningkatan efisiensi pelayanan publik skala kelurahan.

Pada peringkat kedua terkait persetujuan masyarakat dan aparat kelurahan adalah pada pernyataan yang terkait dengan (1) partisipan setuju bahwa selama ini mereka mengalami kesulitan dalam memperbaharui data peta/data spasial dan (2) SIG dapat diterapkan di kelurahan secara menerus. Dari penilaian pada skor pada 4.3, dapat dipahami bahwa permasalahan terkait pengadaan data digital memang ada, dan pemanfaatan secara menerus data digital pada kelurahan adalah memungkinkan. Hanya saja, untuk yang terakhir, pelatihan ulang atau memperbaharui pemahaman aparat dan masyarakat bisa jadi merupakan faktor penting untuk keberlanjutan implementasi SIG pada skala kelurahan.

Nilai yang paling rendah terkait dengan pernyataan bahwa SIG mudah dipahami. Hal ini bisa menjadi perhatian bagi upaya penerapan SIG di kelurahan bahwa sangat mungkin dibutuhkan lebih dari satu kali workshop dalam upaya memberikan pemahaman praktis terkait SIG di kelurahan. Hal ini bisa menjadi masukan penting bagi akademisi dalam penyelenggaraan workshop.

Selanjutnya, berdasarkan penjelasan yang lebih detil dari responden terhadap setiap pertanyaan yang diajukan di atas, dapat dipahami bahwa menurut responden, SIG bisa membantu peningkatan efisiensi pelayanan karena software SIG ini dapat mempermudah aparat dan masyarakat dalam memetakan masalah-masalah yang terkait dengan perkembangan spasial atau keruangan. Selain itu, masyarakat dan aparat bisa dengan mudah mengakses data yang sudah tersimpan dalam sistem. Sehingga, aparat dan masyarakat kelurahan mampu melakukan intervensi kebijakan skala kelurahan secara lebih cepat.

Sedangkan kesulitan untuk memperbaharui data spasial skala kelurahan yang dialami masyarakat selama ini adalah karena mereka tidak menggunakan aplikasi SIG, aparat dan masyarakat tidak memahami bagaimana data-data spasial tersebut sebaiknya diperbaharui secara berkala pada peta konvensional secara efisien.

\section{Kesimpulan}

Efektivitas kinerja perangkat daerah, termasuk pada level kelurahan, dalam perencanaan dan pengendalian pemanfaatan lahan, dapat dilakukan melalui pengembangan kapasitas aparat kelurahan dalam menjalankan pelayanan publik terkait tata ruang. Optimalisasi dapat dilakukan dengan memanfaatkan teknologi informasi geospasial dalam pelayanan publik, termasuk perumusan kebijakan terkait tata ruang. Dalam hal ini, pelibatan Perguruan Tinggi melalui kegiatan kemitraan masyarakat dapat menjadi solusi dalam mengatasi keterbatasan kapasitas Pemerintah Daerah dalam menyediakan sumber daya, baik perangkat keras dan lunak serta sumber daya manusia. 
Hasil penelitian ini mengungkapkan juga bahwa aparat kelurahan serta masyarakat dapat berpartisipasi dalam pengembangan data spasial kelurahan berbasis sistem informasi geografis. Partisipasi secara efektif dapat dilakukan jika didukung oleh ketersediaan perangkat keras, perangkat lunak, misalnya berupa aplikasi ArcGIS 10.3, serta workshop pembaharuan operasionalisasi perangkat lunak ArcGIS sebagai media pengembangan kapasitas SDM.

Aparat kelurahan dan masyarakat diharapkan dapat memanfaatkan kapasitas yang telah dimiliki secara mandiri dan kolaboratif guna melakukan pemberdayaan serta pembaharuan database informasi kelurahan dalam bentuk peta, serta menjadikannya sebagai salah satu alat pengendalian pemanfaatan ruang.

\section{Referensi}

[1] Aini A n.d. Sistem Informasi Geografis Pengertian dan Aplikasinya P3M STMIK AMIKOM Yogyakarta Diakses dari http://p3m.amikom.ac.id/p3m/dasi/juni07/02\%20\%20STMIK\%20AMIKOM\%20Yogyakarta\%20Sistem\%20Informasi\%20Geografi,\%20Pe ngertian\%20dan\%20Pemanfaatannya.pdf

[2] Singh A 2019 Remote sensing and GIS applications for municipal waste management. Journal of Environmental Management $243 \quad 1$ pp 22-9 DOI: 10.1016/j.jenvman.2019.05.017

[3] Adeyeyea O A, Ikpokontea E A dan Arabu S A 2019 GIS-based groundwater potential mapping within Dengi area, North Central Nigeria The Egyptian Journal of Remote Sensing and Space Science 222 pp 175-81 DOI: 10.1016/j.ejrs.2018.04.003

[4] Cecílio I S, Chiquieri J, Freitas R R dan Gonçalves W 2019 Holistic analysis of the Vehicle Routing Problem: an approach for GIS-T International Journal of Advanced Engineering Research and Science (IJAERS) 69 pp 16-31 DOI: 10.22161/ijaers.69.13

[5] Bo F, Danlin Y, Yaojun Z 2019 The livable urban landscape: GIS and remote sensing extracted land use assessment for urban livability in Changchun Proper, China Land Use Policy 87 pp 1-11 DOI: 10.1016/j.landusepol.2019.104048

[6] Chowdhury M, Hasan M E dan Abdullah-Al-Mamun M M 2020 Land use/land cover change assessment of Halda watershed using remote sensing and GIS The Egyptian Journal of Remote Sensing and Space Sciences 231 pp 63-75 DOI: 10.1016/j.ejrs.2018.11.003

[7] Sosiawan E A dan Pujiastuti E E 2009 Model Manajemen Komunikasi dan Administrasi Back Office E-Government sebagai Media Pelayanan Publik Jurnal Ilmu Komunikasi 7 1 pp 67-83 Diakses dari https://www.neliti.com/id/publications/102717/modelmanajemen-komunikasi-dan-administrasi-back-office-e-government-sebagai-med

[8] Nyeko M 2012 GIS and Multi-Criteria Decision Analysis for Land Use Resource Planning Journal of Geographic Information System $4 \quad 4 \quad \mathrm{pp} 341-8$ DOI: 10.4236/jgis.2012.44039

[9] Yin R K 2014 Case Study Research Design and Methods (5th ed.) (Thousand Oaks, CA: Sage) 